\title{
No Better Time Than Now: Future Uncertainty and Private Investment Under Dictatorship
}

\author{
Michael Albertus* Victor Gay ${ }^{\dagger}$
}

September 2018

\begin{abstract}
Despite received wisdom that long time horizons and formal institutions can induce private investment under dictatorship, there is substantial investment even in relatively unconstrained regimes. This paper provides a novel explanation for the puzzle of investment in these regimes: economic elites' uncertainty over expected investment returns under plausible alternative authoritarian successors. We construct a noisy signaling model that captures how uncertainty over which type of authoritarian successor will rule next and uncertainty in the truthfulness of policy promises made by potential autocratic successors might provide incentives for elite investment.
\end{abstract}

${ }^{*}$ Corresponding author: Department of Political Science, University of Chicago, 5828 S. University Avenue, Pick Hall 426, Chicago, IL, 60637 (albertus@uchicago.edu).

${ }^{\dagger}$ Toulouse School of Economics (TSE) and Institute for Advanced Study in Toulouse (IAST), University of Toulouse Capitole, Manufacture des Tabacs, 21 Allée de Brienne, 31015 Toulouse, France (victor.gay@tsefr.eu). 
Scholarship on property rights and institutional checks and balances has long emphasized that because democracies are characterized by greater institutional constraints than autocracies, property rights in democratic settings are more secure (Olson 1993, North 1990, North \& Thomas 1973). By contrast, weaker institutional constraints under dictatorship render private citizens and even elites more vulnerable to expropriation and harassment (Albertus 2015, Ansell \& Samuels 2014). Domestic investment under dictatorship can therefore be a risky endeavor: investors may not only face predation on their income streams, but also risk losing their initial capital invested.

Yet domestic investment is hardly absent under dictatorship. For example, East Asian developmental states such as Communist China were built on an authoritarian foundation (Evans 1995), as was the Mexican economic miracle (Haber, Maurer \& Razo 2003). While states played a key role in stoking growth in these cases, domestic investment was also substantial in these regimes.

Existing research offers several principal explanations for private investment under dictatorship. One is that dictators with long time horizons have an encompassing interest in their economies, leading them to cultivate investment and growth rather than predating on their populations (Olson 1993, Wintrobe 1998). Another explanation stems from the finding that formal institutions in autocratic regimes - especially legislatures and entrenched political parties - contribute to regime stability by playing the role of monitoring devices of power sharing agreements (Svolik 2012, Magaloni 2008); by increasing information flows among insiders about the violation of property rights (Gehlbach \& Keefer 2011); and by facilitating collective action to resist dictator overreach (Gandhi 2008, Gehlbach \& Keefer 2012). Formal institutions consequently help dictators solve the problem of commitment to their supporting coalition, reducing the likelihood of expropriation and coaxing private actors to invest in economic activity. These institutions also constrain rent-seeking, encouraging citizens to seek profits through investment in production rather than through lobbying (Krueger 1974).

The explanatory power of these arguments alongside substantial empirical evidence, however, has resulted in considerably less investigation of determinants of investment in uninstitutionalized dictatorships. Yet numerous examples such as Argentina under military rule in the mid-late 20th century, Bangladesh under personal rule in the early 1980s, the Philippines 
under Marcos, Chile under Pinochet, and Thailand and Myanmar under a string of military rulers suggest that private investment is hardly absent, and can even be quite significant, in many uninstitutionalized dictatorships. Private actors oftentimes invest heavily in the economy under these rulers despite the lack of anything like an ironclad guarantee that their returns and underlying assets would be respected.

This paper examines this puzzle systematically: why does substantial domestic investment occur even under relatively unconstrained dictatorships? We focus on economic elites' calculations regarding whether or not to invest under dictatorship. In particular, we examine a relatively understudied but crucial determinant of investment: uncertainty over expected economic returns under plausible alternative authoritarian successors.

Investors worry about the policies chosen by autocratic successors. We unpack this theoretically and examine specific mechanisms through which economic elites form beliefs about likely future policies. We outline two major mechanisms by which uncertainty manifests in the investment decisions that economic elites make under dictatorship. We refer to these as "elite uncertainty."

The first source of uncertainty resides in the set of potential subsequent autocrats. Median dictator tenure in office since 1875 is two years, and more than $90 \%$ of autocrats are replaced by a new autocrat. ${ }^{1}$ This typically rapid leader replacement can give economic elites pause over the identity and likely policies of the next dictator. To be sure, institutionalized selection procedures, such as election by a politburo or regularized appointment by a military high command, can at times render the set of potential autocrats and the likely policies they would implement in office more predictable. By contrast, a new leader that rises from a widely varying pool might have little affinity to economic elites and instead attempt to predate upon or expropriate them. This is especially important because many types of investment take time to yield profits and require substantial capital investments to generate subsequent returns. This uncertainty can lead elites to invest under the present dictator, even if expropriation risk is not especially low.

Knowing that this first source of policy uncertainty makes economic elites wary of waiting to invest under the next autocrat, potential autocrats have incentives to try to signal that

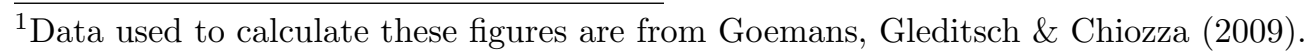


they would be reliable patrons to economic elites if installed in office. After all, private investment can benefit autocratic rulers by fostering regime stability, spurring economic growth, and generating resources that can be taxed, skimmed for rents, or shared with a ruling coalition. But the fidelity of an autocrat's signals to economic elites is a second source of elite uncertainty. Many potential autocrats have incentives to promise to uphold economic elite interests, both those who are members of the economic elite or allied to them, as well as those who merely seek to exploit elite support to aid their rise to power and then later betray them, seizing their investments while appealing to the masses, to a narrow military clique, or to a personal coalition. Of course, economic elites recognize this dynamic, and therefore take care to distinguish allies from enemies. But communication between economic elites and would-be dictators often occurs in an uncertain, and typically secret, environment. The presence of an autonomous but fractionalized military, or political instability in the form of an ongoing insurgency or regional separatism, makes it harder for economic elites to garner precise and credible information from a potential autocrat's signals. This inhibits their ability to identify faithful autocratic patrons.

We argue that these dynamics drive a seemingly counterintuitive finding from the perspective of traditional theories of investment: that investment can actually increase as uncertainty rises. Economic elites who are uncertain about what will transpire under the next dictator might have incentives to invest today in order to realize returns and take advantage of a relatively more favorable investment environment. In other words, economic elites use investment as a vehicle to transfer wealth across states of the world characterized by varying levels of uncertainty, and a more uncertain future makes investment under a present dictator relatively more attractive. This is true even if the current environment is characterized by significant expropriation risk. Such outcomes are not uncommon. Indeed, we find that private domestic investment in the least constrained dictatorships is above the average for all dictatorships in roughly one-third of observations of unconstrained dictatorships.

We build a noisy signaling model that captures these dynamics. At the core of our model, a potential autocrat seeks to convince economic elites that he would faithfully hue to their interests if he rises to office. This enables us to generate comparative statics regarding how uncertainty impacts whether or not economic elites will invest in the economy. We find that 
more uncertainty in the set of potential autocrats and greater noise in the informational environment lead elites to invest more in economic activity. The model therefore offers a new mechanism that aids in understanding a host of cases of investment under dictatorship that are perplexing from the perspective of existing theory.

The remainder of this paper continues as follows. The first section outlines the main existing explanations for private investment under dictatorship and highlights a set of cases that are puzzling under these explanations and to which our theory most likely applies. The second section builds a formal model of our elite uncertainty mechanism, elucidating the sources of uncertainty that drive economic elites toward investing under a current dictator and providing a set of predictions about when this will happen. The third section bounds the likely generalizability of the mechanism and provides a brief illustrative overview of several cases in which it has operated.

\section{Existing Explanations of Private Investment Under Dictatorship and Puzzling Cases}

Several strands of literature seek to explain private investment under dictatorship. One prominent and longstanding explanation is that dictators with long time horizons have incentives to stoke investment and growth rather than predate on citizens in order to grow the size of the economy, and with it the size of their rents (Olson 1993, Wintrobe 1998). ${ }^{2}$ Time horizons are in turn linked with age and time in office. Older leaders entering office have shorter time horizons and are more likely to cultivate myopic coalitions and pursue parochial interests (Olson 1993). By contrast, because the likelihood of violent displacement decreases monotonically with a leader's tenure in office (Svolik 2012), long-lived leaders with security of office are likely to have longer time horizons (Levi 1989).

A separate explanation for private investment under dictatorship is institutionalization. Formal institutions ease the ability of dictators to credibly commit to acting in the interests of their supporting coalition, reducing the threat of arbitrary expropriation and encouraging

\footnotetext{
${ }^{2}$ For a dissenting view that ties longstanding authoritarian control to the shuffling of delegates, which can hamper investment, see Debs (2007).
} 
private actors to invest in economic activity (Bates \& Lien 1985, North \& Weingast 1989). Legislatures and political parties are particularly effective in this regard. First, they can be used to monitor and police the limits of an autocrat's power (Svolik 2012, Magaloni 2008). Second, they can empower actors to sanction the leader by granting them resources and the power to stoke collective action (Gandhi 2008, Gehlbach \& Keefer 2012, Wilson \& Wright 2017). Finally, they can increase information flows among insiders about the violation of property rights (Gehlbach \& Keefer 2011). ${ }^{3}$

There are, however, a number of cases of significant private investment under dictatorship that are puzzling from the perspective of these literatures. Figure 1 helps to capture this puzzle. This figure plots the density of private domestic investment as a percentage of GDP. Domestic private investment is calculated as gross fixed capital formation in the private sector as a percentage of GDP minus foreign direct investment (FDI) as a percentage of GDP. Data are from the World Bank Development Indicators and cover the period 1970-2008. ${ }^{4}$

Figure 1a first differentiates between democracies and dictatorships. Regime type data are from Cheibub, Gandhi \& Vreeland (2010). Following Przeworski et al. (2000), these authors code regimes as either democracies or dictatorships. Democracies are regimes in which (1) the chief executive is elected; (2) the legislature is elected; (3) there is more than one political party; and (4) an incumbent has lost power and transferred it peacefully to a new leader. Dictatorships are regimes that fail to meet all of these criteria. Figure 1a shows that democracies have on average somewhat higher rates of private investment than dictatorships. ${ }^{5}$

Figure 1b turns exclusively to dictatorships. Private domestic investment under dictatorship ranges from $0-70.5 \%$ of GDP and has a mean of $11.0 \%$ with a standard deviation of 7.5\%. Figure 1b differentiates between two different sets of dictatorships that reflect com-

\footnotetext{
${ }^{3}$ Formal institutions may be less constraining, however, in certain types of dictatorships such as personalist regimes (Wilson \& Wright 2017). Furthermore, some recent contributions such as Jensen, Malesky \& Weymouth (2014) have challenged the notion that authoritarian legislatures constrain expropriation at all. ${ }^{4}$ Domestic private investment is calculated as zero in the small number of cases where FDI exceeds gross fixed capital formation given that some FDI does not flow to fixed capital assets. Figure 1 is also similar when focusing on both domestic and foreign private investment.

${ }^{5}$ While this is anticipated by most literature, it contradicts some recent findings (Gehlbach \& Keefer 2011).
} 
mon expectations for trends in private investment. The first set of dictatorships are those that face institutional constraints in the form of a functioning legislature or one or more dominant, institutionalized political parties, as well as monarchies, which are expected to have especially long time horizons even absent these institutions (Herb 1999). ${ }^{6}$ Data on legislatures, parties, and monarchies are from Geddes, Wright \& Frantz (2014) and Gandhi (2008). ${ }^{7}$ The second set of dictatorships are a residual category: those that face no measurable institutional constraints or institutionalized parties and that are not monarchies. The latter set of dictatorships comprise $18 \%$ of the sample of over 1,000 dictatorship-years for which data on institutions and private domestic investment are available. ${ }^{8}$

One striking trend in Figure $1 \mathrm{~b}$ is that while dictatorships that do not face institutional constraints or enjoy long time horizons have slightly lower rates of private investment than those dictatorships that do face institutional constraints, the differences are not large. ${ }^{9}$ The mean private domestic investment ratio in institutionally constrained dictatorships is $11.3 \%$ of GDP with a standard deviation of $7.3 \%$, whereas the mean private investment ratio in institutionally unconstrained dictatorships is $8.9 \%$ of GDP with a standard deviation of $6.7 \%$. Furthermore, $33 \%$ of the dictatorship-years of institutionally unconstrained dictatorships have higher rates of private investment than the average under institutionally constrained dictatorships. In many of these cases, dictators are not especially long-lived, and therefore are unlikely to have had long time horizons and an encompassing interest in the economy.

One potential explanation for this puzzle could be that private investment is driven by politically connected elites that benefit from government policies. Elites that are allied to the autocrat may invest because they think that any expropriatory policies selected by the unconstrained autocrat will help rather hurt them (Sonin 2003). Indeed, this dynamic undergirds the common assumption in the literature that the economic elite are aligned with the ruler (Acemoglu \& Robinson 2006, Pond 2018). There is ample evidence, from

\footnotetext{
${ }^{6}$ Results are similar including hybrid single party regimes.

${ }^{7}$ The temporal coverage of Figure $1 \mathrm{~b}$ is limited by the data on authoritarian legislatures, which ends in 2002.

${ }^{8}$ This set likely undercounts relatively unconstrained dictatorships by including some cases where legislatures or parties are weak and serve as rubber stamps.

${ }^{9}$ The difference in private investment is even smaller if we consider only institutionalization and do not treat monarchical rule separately.
} 
Putin's Russia to Erdogan's Turkey, that some considerable portion of private investment in autocracies can derive from the politically connected elite. Yet this simple observation cannot fully explain the puzzle of elite investment in unconstrained regimes for two reasons.

First, dictators are displaced not infrequently, and elites are attuned to the uncertainty that this induces for their investments. Indeed, political allies of the current dictator might be particularly attuned to this dynamic: if the current investment environment for them is favorable due to political connections, then the future under an alternative leader might be especially risky. Personalized ties may not be replicated in the future without any institutionalized support, and a former dictator's allies might become the targets of a purge.

At the same time, ample evidence suggests that private investment hardly comes only from the politically connected under dictatorship. Consider, for instance, the rise of industrialization, in which rising outsider economic elites tied to industry invested in spite of often being at loggerheads with ruling political elites who were closely linked with landed classes (Ansell \& Samuels 2014). A range of recent literature demonstrates not only this fractionalization of elites and of elite/dictator relationships (Ansell \& Samuels 2014, Albertus \& Menaldo 2014, Mares \& Queralt 2015), but also that outsider economic elites - those not dependent upon the incumbent regime for their profits - often invest heavily even under dictatorship (Ansell \& Samuels 2014, Albertus \& Menaldo 2018).

Many cases of substantial private investment under institutionally unconstrained dictatorships have occurred under circumstances of recent political instability and uncertainty over the likely consequences of future leadership changes. One illustrative case is Argentina in the late 1970s-early 1980s. Economic pressures and popular resistance gave business little faith in the military rulers Levingston and Lanusse in the early 1970s aside from the powerful agro-exporters of the Sociedad Rural Argentina, which won a number of direct government posts (Schneider 2004, 186). This was all the more the case due to their vacillating positions on the Peronists, who advocated redistribution and tariffs to favor the interests of urban laborers. A brief return to democracy under Perón in the mid-1970s yielded a coup and the return to narrow military rule under General Videla, who was a more steadfast ally of business. Yet amidst Argentina's notorious political instability, there was little certainty over how long Videla would last or whether he might be replaced by another Videla-like 
general or an unfavorable military faction led by a general more similar to Levingston or Lanusse, or even an elected leader sympathetic to the Peronists. Consequently, economic elites in selected sectors poured money back into the economy under Videla. Business came to control a number of key economic decisions as "a corporative network between the public and private sector was consolidated and favored the most concentrated capital fractions" (Castellani 2013, 101). This was especially the case in privatized former state industrial enterprises, finance, and petroleum production.

Political instability and associated uncertainty have reigned in a host of other unconstrained dictatorships where private investment has surprisingly flourished. Private investment spiked under Marcos in the Philippines despite his checkered record on supporting business and concerns over who might replace him-whether an unreliable military general, a leftist takeover, or an elected leader from ideologically wide-ranging and splintered political parties (Celoza 1997, 88-91; 96-99). ${ }^{10}$ Business investment has been formidable under a series of Thai military regimes in the 1970s, early 1990s, 2000s, and again since 2014, despite the military repeatedly shutting down institutional checks to their power and at times attempting to extend their rule arbitrarily and implementing policies that alienate elites (e.g., the Tax Increase Bill of 1970). Many of these military regimes have been viewed by business elites as merely a better bet than rule either by alternative military factions or representatives of the ascendant popular classes. ${ }^{11}$ Similarly high private investment amidst political instability and uncertainty also characterizes Mauritania in the mid-1970s and midlate 1980s, Algeria in the 1990s, Uruguay in the 1970s, and Bangladesh in the early 1980s and again in the late 2000s.

We do not argue that private investor uncertainty over future outcomes explains investment under dictatorship in all cases that are otherwise puzzling. But as Section 3 discusses in greater depth, a range of cases demonstrate the operation of our proposed mechanism.

Finally, there are some reasons to believe that prospective autocrat signaling to economic elites is even more important for investment in the current, post-Cold War era.

${ }^{10}$ Oligarchic support for Marcos was, however, highly fractionalized, and support waned over time as he attacked selected oligarchic families and sectors (Slater 2010).

${ }^{11}$ As Crone (1991, 101-102) details, army factionalism was rife by the 1970s and 1980s, particularly between the junior "Young Turks" and the senior "Democratic Soldiers." 
During the Cold War, although ideological divisions were heavily entrenched, they did not always map neatly and predictably onto redistributive policies, especially in certain parts of the developing world where dictatorship was prevalent (Albertus 2015, Huber, Mustillo \& Stephens 2008). But these divisions and their consequences have certainly become less clear-cut since the Cold War's end, as witnessed by the phenomenon of left-leaning parties sometimes adopting market-oriented reforms. Consequently, signaling in such an environment becomes a particularly relevant mechanism for elites to attempt to decipher the type of potential autocrats that might rise to power.

\section{A Model of Private Investment Under Dictatorship Amidst Investor Uncertainty}

The formal game-theoretic model that we develop captures the idea that investor uncertainty may induce investment despite certain expropriation risk. Our model is an adaptation of a noisy signaling model from Cunningham \& de Barreda (2015). ${ }^{12}$ In the model, the sender's type is drawn from a continuous distribution and the receiver's action is binary.

Many formal models of politics under authoritarianism examine pervasive commitment problems in dictatorships: because there is no independent third party enforcer of agreements, an authoritarian leader make ex ante promises to supporters and then renege upon rising to office (Boix \& Svolik 2013, Gehlbach \& Keefer 2011, Magaloni 2008, Myerson 2008). These models then explore how authoritarian institutions or coalitions of insiders form to resolve these commitment problems. Different from these important contributions, our noisy signaling model builds on existing literature by examining information asymmetries that arise between potential autocratic successors and economic elites that stem from imperfect information about autocratic successors' types. Specifically, the model explores the implications of information asymmetries between economic elites and "dictator candidates" in the presence of commitment problems.

\footnotetext{
${ }^{12}$ One application of this model, with a focus on democratization, is Albertus \& Gay (2017). Unlike that model, our basic model, which examines investment, operates in an authoritarian equilibrium. Furthermore, dictator turnover is exogenous to economic elites in our baseline model.
} 
Fundamentals and Incentives We analyze interactions between two players over two time periods: investors and a potential autocrat. We also term investors as economic elites in our discussion given their capacity to either withhold or deploy capital. Autocrats are characterized by their type, $\theta \in[0,1]$. This represents their alignment with the interests of economic elites, and directly maps onto their expropriation behavior. A type $\theta=1$ characterizes an autocrat that is fully aligned with economic elites, and who does not expropriate their investments when in power. Conversely, a type $\theta=0$ characterizes an autocrat that is not at all aligned with economic elites, and who has strong incentives to expropriate their investments when in power. A related interpretation for $\theta$ is that some dictators may be more tempted than others to expropriate under the same conditions.

The autocrat's type $\theta$ is often modeled as a behavioral outcome in equilibrium. In other words, the ruler strategically decides whether and how much to expropriate as a function of constraints (North \& Weingast 1989, Olson 1993). While we certainly do not deny that dictators respond to incentives, we seek to highlight the implications of a different dynamic that has received increasing attention in recent years: there is wide variation in dictator alignment with economic elites, even within the same country over time (Albertus 2015, Ansell \& Samuels 2014). This alignment is driven by factors such as elite competition, state autonomy, and modernization. The upshot is that some dictators are inherently less willing to expropriate than others as a consequence of ideology or intra-elite relations. We focus explicitly on the implications of this observation for investment, and, in a departure from the existing literature, consequently treat $\theta$ as exogenous to the potential dictator.

For example, a dictator drawn from a tight-knit landed elite in an agrarian country may be much less likely to expropriate investment in that sector than a dictator who arises from the urban working class in the same country. Whereas the latter dictator may see landed elites as a threat and value modernization and urban primacy, the former dictator is more likely to have a dense web of social relationships with landowners and to tie social prestige to landholding. In El Salvador, for instance, "[b]etween 1913 and 1927, interlocking family clans with large landholdings dominated the Salvadorean polity" (Almeida 2008, 37). Despite facing few institutional constraints, the dictators drawn from these families in this period refrained from expropriating landed interests. To the contrary, these rulers were large 
landowners' staunchest defenders.

A critical underlying assumption of our model, and one which follows the scholarly consensus regarding commitment problems under authoritarianism, is that a dictator candidate cannot credibly commit ex ante to economic elites to implement a policy once in office that deviates from his type. This commitment problem implies, for instance, that a potential autocrat cannot commit to refrain from expropriating investors in order to increase the likelihood that investors will hold on to their assets to invest once he is in power. Instead, autocrats implement policies that are fully aligned with their ideology or "type." It is therefore critical for would-be investors to learn about the true identity of potential autocrats before deciding whether to simply invest under the current autocrat or to instead withhold their capital in hopes of investing it under a more favorable subsequent autocrat.

In the first period of the model, a current autocrat is in office. He is of type $\bar{\theta}$, which is public information. He is replaced in the second period by a potential autocrat with probability $\bar{p} .^{13}$ The potential autocrat's type is a random variable drawn from uniform distribution $F(\cdot)$ with density $f(\cdot)$ over $[\mu-b, \mu+b] \subseteq[0,1]$. The type is private information to the potential autocrat and is spread around the mean $\mu$ up to a distance of $b=\left(3 \sigma_{\theta}^{2}\right)^{1 / 2}$, where $\sigma_{\theta}^{2}$ is the variance in the distribution of types. ${ }^{14}$ This variance $\sigma_{\theta}^{2}$ characterizes economic elites' uncertainty over the pool of potential autocrats.

Economic elites have a unit endowment available for investment in the domestic economy. They can either invest their endowment under the current autocrat $(a=0)$ or wait until the next period to invest $(a=1)$. If they invest under the current autocrat, they get an immediate rate of return of $r \in[0,1]$. However, part of their investment is expropriated and they only get to keep a share $\bar{\theta}$ of their investment and of its returns. They have no return in the second period. If they wait until the next period to invest, they get a rate of return of $r$ and keep a share $\theta$ of their investment, where $\theta$ is the type of the autocrat in power in that period. ${ }^{15}$

\footnotetext{
${ }^{13}$ In the basic version of the model, the likelihood of an autocrat turnover is exogenous. In extension 5 , we endogenize $\bar{p}$ and examine its effects when it varies as a function of elite investment.

${ }^{14}$ Given that $[\mu-b, \mu+b] \subseteq[0,1], \sigma_{\theta}^{2}$ cannot be too large: $\sigma_{\theta}^{2} \leq \min \left\{\mu^{2} / 3,(1-\mu)^{2} / 3\right\} \leq 1 / 12$, where $1 / 12$ is the maximum attained by $\min \left\{\mu^{2} / 3,(1-\mu)^{2} / 3\right\}$.

${ }^{15}$ If economic elites do not invest in the first period, they keep their unit endowment until the next period
} 
It is important to underscore that assumptions regarding the structure of elite investment do not alter the generality of the uncertainty mechanisms we highlight. If, for instance, economic elites are presented with an outside option-not investing at all and instead postponing the investment of their unit endowment indefinitely - this does not alter the predictions of the model (extension 1). Our results are similarly unchanged when providing economic elites with yet another outside option, investing abroad (extension 2), or when investment in the first period generates returns in both periods (extension 3).

The potential autocrat gets a payoff of zero if there is no autocrat turnover. In the case of an autocrat turnover, he gets a payoff of one if economic elites invest their endowment under his rule, and zero if they invested under the previous autocrat. ${ }^{16}$ As mentioned above, private investment can benefit an autocrat by fostering regime stability, catalyzing economic growth, and generating resources that can be taxed, skimmed for rents, or distributed among a ruling coalition. For simplicity, the autocrat's payoff is independent of his type.

Uncertainty in the pool of potential autocrats We first provide intuition for why uncertainty over the pool of potential autocrats generates incentives for economic elites to invest under the current autocrat despite some expropriation risk. Suppose that the potential autocrat cannot signal his type to economic elites. If economic elites perfectly observed the potential autocrat's type once its value was realized, their decision rule would be to invest under the current autocrat as long as they are better off than keeping their unit endowment and investing it in the next period. Their payoff when investing under the current autocrat would be $(1+r) \bar{\theta}$. Given the likelihood of autocrat turnover $\bar{p}$ and the realization of the potential autocrat's type $\theta$, their expected payoff when investing in the next period would be $(1+r)[(1-\bar{p}) \bar{\theta}+\bar{p} \theta]$.

However, the potential autocrat's type is his private information; economic elites only know its probability distribution when they make their investment decision. As a result, the

without the risk of being expropriated by the current autocrat. In this case, the endowment does not depreciate (see footnote 31). Without loss of generality, we set the discount rate to one. Extension 4 relaxes this assumption.

${ }^{16}$ For simplicity, we do not add an exogenous ego rent from holding power. Doing so would not alter incentives on the margin. 
probability of elite investment under the current autocrat is: ${ }^{17}$

$$
\operatorname{Pr}(\text { elite investment })=\operatorname{Pr}(\theta \leq \bar{\theta})=\frac{1}{2}-\frac{\nu}{2 b}
$$

where $\nu=\mu-\bar{\theta}$ is the expected benefit to economic elites of investing under the potential autocrat relative to the current autocrat. ${ }^{18}$

Consider first a benchmark case in which the regime is "investor friendly", i.e., when the current autocrat is more favorable to investors than the average autocrat $(\bar{\theta}>\mu)$. As is intuitive and anticipated by previous research, higher uncertainty over autocratic alternatives in this case generates less investment. This mechanism nevertheless only channels through uncertainty with respect to the pool of potential autocrats, not through uncertainty with respect to the informational environment. ${ }^{19}$

We focus, by contrast, on a previously undertheorized and underexamined class of regimes in which the current autocrat is not favorably aligned with investors, i.e., regimes in which $\bar{\theta}<\mu$. In this setting, higher uncertainty in the pool of potential autocrats generates more elite investment despite certain expropriation risk. This is an interesting and heretofore puzzling set of cases. Furthermore, variation in elite investment across regimes with differential levels of uncertainty is likely to be much more substantial in this class of regimes than it is in "investor friendly" regimes once base rates are taken into account. Why is this the case? Elite investment is more likely in investor friendly regimes than in investor unfriendly regimes at their onset - the probability of elite investment in investor friendly regimes is strictly above $1 / 2$, whereas it is below $1 / 2$ in unfriendly regimes. Consequently, any changes in elite investment resulting from varying levels in uncertainty is likely to be small in investor friendly regimes relative to uncertainty-induced changes in investment in unfriendly regimes;

17 The derivation is as follows: $\operatorname{Pr}($ elite investment $)=\operatorname{Pr}((1+r)[(1-\bar{p}) \bar{\theta}+\bar{p} \theta] \leq(1+r) \bar{\theta})=$ $\operatorname{Pr}(\theta \leq \bar{\theta})=[\bar{\theta}-(\mu-b)] /[(\mu+b)-(\mu-b)]=(\bar{\theta}-\mu+b) / 2 b=1 / 2-(\mu-\bar{\theta}) / 2 b$.

${ }^{18}$ Because the current autocrat is drawn from the same distribution as potential autocrats, $\bar{\theta} \in[\mu-b, \mu+b]$. As a result, the probability of elite investment is always between 0 and 1.

${ }^{19}$ Mathematically: $\partial \operatorname{Pr}\left(\right.$ elite investment) $/ \partial \sigma_{\theta}^{2}=\left(\nu / 2 b^{2}\right)\left(\partial b / \partial \sigma_{\theta}^{2}\right)$. Because $\partial b / \partial \sigma_{\theta}^{2}=3 /\left[2\left(3 \sigma_{\theta}^{2}\right)^{1 / 2}\right]>0$, the sign of the comparative statics only depends on the sign of $\nu$. This sign dependence upon the parameter space nevertheless does not matter for uncertainty with respect to the informational environment (see footnote 25$)$. 
as the regime becomes more "investor friendly" ( $\bar{\theta}$ increases relative to $\mu$ ), the relative change in elite investment following an increase in uncertainty unambiguously declines. ${ }^{20}$

How does elite investment compare across "unfriendly" regimes with different levels of uncertainty in the pool of potential autocrats? Consider two regimes, A and B, with an identical current autocrat of type $\bar{\theta}=0.4$, but with different variances in their distributions of potential autocrats. Figure 2 plots densities of types across these two regimes. While both distributions have the same mean $\mu=0.5$, regime $\mathrm{A}$ is characterized by a higher variance than regime $\mathrm{B}\left(\sigma_{A, \theta}^{2}=0.08>0.02=\sigma_{B, \theta}^{2}\right)$. The density in regime $\mathrm{B}, f_{B}$, has a lower bound that is above that of regime $\mathrm{A}, f_{A}$. Therefore, the density of potential types below threshold $\bar{\theta}$ is larger in regime $\mathrm{A}$ than in regime $\mathrm{B}$. As a result, elite investment is more likely under regime A. ${ }^{21}$

The role of uncertainty over the pool of potential autocrats explains why elite investment might be higher in a regime with high expropriation risk than in a regime with low expropriation risk. Consider Figure 3. This figure plots the ratio of elite investment across two regimes as a function of the type of the current autocrat in regime $\mathrm{A}, \bar{\theta}_{A}$, given that the type of autocrat in regime $\mathrm{B}$ is $\bar{\theta}_{B}=0.4$. Suppose first that both regimes have the same distributions of potential autocrats $\left(\mu=0.5\right.$ and $\left.\sigma_{A, \theta}^{2}=\sigma_{B, \theta}^{2}=0.02\right)$. The solid line corresponds to the ratio of elite investment across both regimes in this situation. It describes an expected outcome: whenever the current autocrat in regime A is more favorable to economic elites than the autocrat in regime $\mathrm{B}\left(\bar{\theta}_{A}>\bar{\theta}_{B}\right)$, elite investment is higher in regime A than in regime B; the solid line is in the top right quadrant. Conversely, whenever the current autocrat in regime $\mathrm{A}$ is less favorable to economic elites than the autocrat in regime $\mathrm{B}\left(\bar{\theta}_{A}<\bar{\theta}_{B}\right)$, elite investment is lower in regime $\mathrm{A}$ than in regime $\mathrm{B}$; the solid line is in the bottom left quadrant.

Suppose now that regime A has a higher variance in the distribution of potential autocrats $\left(\sigma_{A, \theta}^{2}=4 \sigma_{B, \theta}^{2}=0.08\right)$. The dashed line represents this situation. Because of the relatively

\footnotetext{
${ }^{20}$ The relative absolute change in elite investment following an increase in the variance in the pool of potential autocrats is $\left[\mid \mathrm{d} \operatorname{Pr}\left(\right.\right.$ elite investment) $\left./ \mathrm{d} \sigma_{\theta}^{2} \mid\right] / \operatorname{Pr}$ (elite investment). Differentiating this expression with respect to $-\nu$ yields a strictly negative comparative static.

${ }^{21}$ The area to the left of the threshold $\bar{\theta}$ corresponds to the probability of elite investment from equation 1. In this example, the probability of elite investment is 0.40 in regime A, while it is 0.30 in regime $\mathrm{B}$.
} 
higher uncertainty in the pool of potential autocrats in regime A, elite investment might be higher in that regime despite a relatively less favorable current autocrat. This is the case when the dashed line is in the top left quadrant. Despite higher expropriation risk, elite uncertainty over the pool of potential autocrats might induce economic elites to invest more than in a regime with lower expropriation risk.

Uncertainty in the informational environment We now introduce asymmetric information and allow the potential autocrat to communicate with economic elites. We assume that the potential autocrat's type is his private information. Because economic elites make their investment decisions based on their expectations over the potential autocrat's type, the potential autocrat has incentives to try to convince economic elites that he is more closely aligned with their interests than he actually is. He signals his type by sending a message $m$ to economic elites before they make their investment decision. However, manipulating one's message - lying about one's type - requires some costly effort that is proportional to the distance between the message and the type, $m-\theta$. We model cost of effort by the quadratic cost function $C(m-\theta)=\left[c(m-\theta)^{2}\right] / 2$ so that the slope of the marginal cost of effort is constant at $C^{\prime \prime}(\cdot)=c>0$. Convexity makes the marginal cost of effort larger for lower types than for higher types, which induces the potential autocrat's strategy to have monotone comparative statics, i.e., to be increasing in his type (Ashworth \& Bueno de Mesquita 2006). ${ }^{22}$

Consider an example of potential autocrats signaling their type to economic elites from Peru. Prospective coup plotters and authoritarian leaders for decades sought to signal their sympathy to Peru's tight-knit and powerful elite, a small group of wealthy families that were often organized cognatically and functioned as corporate groups. Prospective leaders were invited to Lima's exclusive Club Nacional, where economic elites sought to assess their favorability through political discussions and social cues such as manners, dress, and patterns of speech (Gilbert 2017, Ch. 5). Some candidates, such as Sánchez Cerro in the early 1930s, successfully signaled their sympathy to elite interests, whereas others, such as Manuel Odría

${ }^{22}$ To see why, first derive the marginal cost of effort: $C^{\prime}(m-\theta)=c(m-\theta)$. The marginal cost of effort is decreasing in the type: $\partial C^{\prime}(m-\theta) / \partial \theta=-c<0$. 
in his later years, did not. This alliance with oligarchs was key to the rise and perpetuation of a raft of dictators from the 1910s through the 1960s. There is evidence of similar signaling by potential autocrats to economic elites from countries such as Bolivia as well (Albertus \& Gay 2017, 637-638).

Economic elites receive the potential autocrat's message with noise. They observe a signal $s=m+u$, where $u$ is a noise drawn from a normal distribution with density $g(\cdot)$, centered around zero, and with a variance $\sigma_{u}^{2}$. This variance $\sigma_{u}^{2}$ characterizes economic elites' uncertainty over the informational environment. In many circumstances, it is difficult for elites to extract verifiable information about the identity and policies of a potential new dictator. For instance, a fractionalized but powerful military that is riven with internal conflict can complicate the ability of investors to discern what potential leader the military might support, or what a military leader would do once in office. Military corruption, whether through complicated and covert ties to disparate business sectors, ties to the drug trade, or deals with foreign actors, only exacerbates this problem. Separately, regional conflict or an ongoing insurgency with ties to politicians can also increase noise in the informational environment.

When economic elites receive the potential autocrats' signal $s$, they update their beliefs about his type following Bayes' rule. Hence, their updated belief is a function of the signal, $s$, and the potential autocrat's messaging strategy, $m$. We denote this function $f(\theta \mid s, m)$. An equilibrium is a pure strategy for the potential autocrat $m:[\mu-b, \mu+b] \rightarrow \mathbb{R}$, and a pure strategy for economic elites $a: \mathbb{R} \rightarrow\{0,1\}$, such that each player's strategy maximizes their expected utility given the other player's strategy, and the beliefs of economic elites are consistent with Bayes' rule:

$$
\left\{\begin{array}{l}
\forall \theta \in[\mu-b, \mu+b], \quad m(\theta) \in \arg \max \int \bar{p} a(m+u) g(u) \mathrm{d} u-C(m, \theta) \\
a(s)=1 \Longleftrightarrow \int \theta f(\theta \mid s, m(\cdot)) \mathrm{d} \theta \geq \bar{\theta}
\end{array}\right.
$$

Proposition 1 (Equilibrium) There exists a unique equilibrium $\left(m^{*}(\cdot), a^{*}(\cdot)\right)$ characterized by a threshold $k^{*}$ such that: ${ }^{23}$

\footnotetext{
${ }^{23}$ This equilibrium holds under the assumption that the cost function is sufficiently convex with $c>$
} 
(a) Economic elites use a threshold decision rule: $a^{*}(s)=1$ if $s \geq k^{*}$, and $a^{*}(s)=0$ if $s<k^{*}$, where the equilibrium threshold $k^{*}$ is such that economic elites are indifferent between investing under the current autocrat and waiting until the next period to invest whenever they receive a signal exactly at the threshold, i.e., $\mathbb{E}\left[\theta \mid s=k^{*}\right]=\bar{\theta}$.

(b) The potential autocrat's equilibrium strategy $m^{*}(\theta)$ is increasing in his type.

(c) The potential autocrat's equilibrium strategy solves: $\bar{p} g\left(k^{*}-m^{*}(\theta)\right)=C^{\prime}\left(m^{*}(\theta)-\theta\right)$.

Proof. See appendix A.

In other words, whenever economic elites receive a signal from the potential autocrat that is above the threshold, they withhold investment in hope for an autocrat turnover. Conversely, whenever they receive a signal that is below the threshold, they invest under the current autocrat. The probability of elite investment for a given threshold $k$ is therefore the probability that the signal they receive is below the threshold given some realization of the noise, $\operatorname{Pr}(m+u \leq k \mid k, u)$. Mathematically, the probability of elite investment for a given threshold $k$ is: ${ }^{24}$

$$
\operatorname{Pr}(\text { elite investment; } k)=\frac{1}{2}-\frac{\nu}{2 b}+\frac{k-\bar{\theta}}{2 b}-\frac{\bar{p}}{2 b c} \int[g(u)]^{2} \mathrm{~d} u .
$$

The first two terms represent the probability of elite investment absent information asymmetries (see equation 1). The third term corresponds to the higher likelihood of elite investment when the threshold $k$ is higher: for each unit of the threshold $k$ above the current autocrat's type $\bar{\theta}$, a density $1 / 2 b$ of types of potential autocrats is considered too unfavorable to economic elites for them to be willing to withhold investment in hope for a turnover in autocrats. The last term corresponds to the precision of the noise, as $\mathbb{E}[g(u)]$ can be interpreted as the concentration of the distribution of the noise. The less precise the signal received by economic elites, the less the potential autocrat has incentives to exert effort to increase the level of his message: economic elites will not be able to extract precise information from this signal and correctly infer the potential autocrat's type. As a result, when the informational $\bar{p} \mathrm{e}^{-1 / 2} / \sigma_{u}^{2} \sqrt{2 \pi}$. The characterization of the equilibrium follows Cunningham \& de Barreda's (2015) Proposition 2.

${ }^{24}$ See appendix B for a derivation. 
environment becomes noisier - the last term decreases - signals are on average lower and less types of potential autocrats are considered aligned enough with economic elites, leading to a higher likelihood of elite investment under the current autocrat. This implies that for a given threshold $k$, higher uncertainty in the informational environment leads to a higher likelihood of elite investment: ${ }^{25}$

$$
\frac{\partial \operatorname{Pr}(\text { elite investment } k)}{\partial \sigma_{u}^{2}}>0
$$

How is the equilibrium threshold $k^{*}$ set? It is such that economic elites are indifferent between investing under the current autocrat and waiting until the next period to invest when they receive a signal exactly at the threshold, i.e., $\mathbb{E}\left[\theta \mid s=k^{*}\right]=\bar{\theta}$. We can write $k^{*}$ as follows: ${ }^{26}$

$$
k^{*}=\bar{\theta}-\frac{\bar{p}}{c} \int u g^{\prime}(u) g(u) \mathrm{d} u>\bar{\theta} .
$$

Note that $u g^{\prime}(u)<0$ because of the symmetry of $g(\cdot)$ around zero. Therefore, $k^{*}>\bar{\theta}$ : the equilibrium threshold is above the current autocrat's type $\bar{\theta}$ that would make economic elites indifferent between investing and waiting for an autocrat turnover. This is because the potential autocrat has incentives to send higher messages than his type. As a result, economic elites are aware that a potential autocrat of type $\bar{\theta}$ must have sent a message above $\bar{\theta}$. Hence, the stronger the incentives for the potential autocrat to lie about his type, such as in an informational environment with little noise, the higher the equilibrium threshold $k^{*}$, resulting in a higher likelihood of elite investment. The effect of uncertainty in the informational environment on elite investment through the equilibrium threshold goes in the opposite direction to the direct effect of uncertainty summarized in equation 3. Importantly, however, we show below that this threshold effect is of second order, and is systematically dominated by the direct effect of uncertainty in the informational environment on elite investment.

Combining the likelihood of elite investment in equation 2 together with the equilibrium threshold in equation 4, we can write the equilibrium probability of elite investment as

25 See appendix $\mathrm{C}$ for a derivation. Note that the sign of this comparative statics does not depend on restrictions of the parameter space, i.e., it is similar for both $\mu>\bar{\theta}$ and $\mu<\bar{\theta}$.

${ }^{26}$ See appendix D for a derivation. 
follows:

\section{Proposition 2 (Equilibrium Elite Investment)}

$$
\operatorname{Pr}(\text { elite investment })=\frac{1}{2}-\frac{\nu}{2 b}-\frac{\bar{p}}{2 b c}\left[\int[g(u)]^{2} d u+\int u g^{\prime}(u) g(u) d u\right]
$$

As before, the first two terms in equation 5 represent the probability of elite investment absent information asymmetries (see equation 1). The first term in brackets corresponds to the precision of the noise, and represents the direct effect of uncertainty in the informational environment on elite investment summarized in equation 3: as the informational environment becomes noisier, the potential autocrat has less incentives to exert effort in lying about his type. As a result, he sends lower signals, which in turn makes elite investment more likely. The second term in brackets represents an opposite effect through the threshold: as the informational environment becomes noisier, the threshold adjusts downwards, making economic elites more likely to wait for an autocrat turnover, thus decreasing the likelihood of elite investment. This indirect effect is dominated by the first, direct effect of uncertainty in the informational environment: using integration by parts, we see that $\int g(u)^{2} \mathrm{~d} u+\int u g^{\prime}(u) g(u) \mathrm{d} u=-\int u g^{\prime}(u) g(u) \mathrm{d} u>0$, because $u g^{\prime}(u)<0$ as the distribution is symmetric around zero.

Overall, elite uncertainty in the pool of potential autocrats and in the informational environment both make elite investment more likely: ${ }^{27}$

$$
\frac{\partial \operatorname{Pr}(\text { elite investment })}{\partial \sigma_{\theta}^{2}}>0 \text { and } \frac{\partial \operatorname{Pr}(\text { elite investment })}{\partial \sigma_{u}^{2}}>0
$$

The role of both types of uncertainty helps explain why elite investment might be higher in a regime with high expropriation risk than in a regime with low expropriation risk. Figure 4 demonstrates this point. Like Figure 3, Figure 4 plots the ratio of elite investment across two regimes as a function of the type of the current autocrat in regime $\mathrm{A}, \bar{\theta}_{A}$, given that the type of the autocrat in regime $\mathrm{B}$ is $\bar{\theta}_{B}=0.4$. The solid line corresponds to the ratio of elite investment across both regimes when they have the same distributions of potential autocrats $\left(\mu=0.5\right.$ and $\left.\sigma_{A, \theta}^{2}=\sigma_{B, \theta}^{2}=0.02\right)$ as well as the same distributions of noise

\footnotetext{
${ }^{27}$ See appendix E for a derivation.
} 
$\left(\sigma_{A, u}^{2}=\sigma_{B, u}^{2}=0.01\right)$. In this situation, the outcome is expected: whenever the current autocrat in regime $\mathrm{A}$ is more favorable to economic elites than the autocrat in regime $\mathrm{B}$ $\left(\bar{\theta}_{A}>\bar{\theta}_{B}\right)$, elite investment is higher in regime $\mathrm{A}$ than in regime $\mathrm{B}$; the solid line is in the top right quadrant.

Now, as in Figure 3, suppose that regime A has a higher variance in the distribution

of potential autocrats $\left(\sigma_{A, \theta}^{2}>\sigma_{B, \theta}^{2}\right)$, keeping uncertainty in the informational environment equal in both regimes. Because of the relatively higher uncertainty in the pool of potential autocrats in regime A, elite investment may be higher in that regime despite a relatively less favorable autocrat; this situation is reflected in Figure 4 when the dashed line is in the top left quadrant.

The dotted line in Figure 4 depicts a third situation. In this case, uncertainty in the pool of potential autocrats is similar in both regimes, but uncertainty in the informational environment is higher in regime $\mathrm{A}$ than in regime $\mathrm{B}\left(\sigma_{A, u}^{2}>\sigma_{B, u}^{2}\right)$. Again, part of the dotted line is in the top left quadrant, suggesting that uncertainty in the informational environment might also induce elite investment despite a relatively high expropriation risk.

\subsection{Model Extensions}

We now introduce various extensions to the model. While these extensions relax several assumptions in our basic model and explore important dynamics relevant to private actors' investment decisions, the fundamental model implication remains: the forms of economic elite uncertainty we identify provide incentives for elite investment under autocracy.

Extension 1: Multiple Periods The basic version of the model assumes two periods. Here, we extend the time horizon to an arbitrary number of periods, enabling economic elites to postpone indefinitely their investment, thereby effectively opening a third option of not investing their endowment at all.

Suppose there are $T+1$ periods, from $t=0$ to $t=T$. Economic elites have a unit endowment, and they choose in which period to invest it. A new potential autocrat is drawn in each period, and has a probability $\bar{p}$ to replace the current autocrat. Draws are i.i.d. across periods. The probability of elite investment under the current autocrat $(a=0)$ is 
$\operatorname{Pr}(\text { elite investment })^{T}$, where $\operatorname{Pr}$ (elite investment) is defined in equation 5 . As a result, the comparative statics in equation 6 hold: higher uncertainty in future periods increases the likelihood of elite investment in the present period (see appendix F).

In short, introducing an arbitrary number of periods does not change the fundamental implications of the model. This is true even for an arbitrarily large value of $T$, such that economic elites effectively withhold from investing their endowment indefinitely.

Extension 2: Investment Abroad Suppose that economic elites have the ability to invest their unit endowment not only domestically but also abroad. If they invest abroad, they receive a rate of return $r^{a}$. To enjoy the fruits of investment, however, they must at some point bring the investment back home. When doing so, first suppose that they face an expropriation rate (or a tax rate) that is similar to the expropriation rate on domestic investment.

Whether economic elites bring the returns of their foreign investment back into the country in the current period or in the next period, the implications of the model still hold. To see why, suppose first that returns can be brought back in the country in the current period. Then, investing abroad yields a total return of $\left(1+r^{a}\right) \bar{\theta}$. Comparing $r^{a}$ with $r$ determines which outside option is binding: if $r^{a}>r$, economic elites compare returns from investing abroad with returns from waiting for the next period, and their outside option becomes $\bar{\theta}\left[1+\left(r^{a}-r\right) /(1+r) \bar{p}\right]$ rather than just $\bar{\theta}$. If returns were brought back in the next period, the binding constraint would similarly be determined by the level of $r^{a}$ relative to $r$.

Allowing the expropriation rate on foreign investment to be different than the expropriation rate on domestic investment similarly does not change the implications of the model, with economic elites comparing $\left(1+r^{a}\right) \bar{\theta}^{a}$ with $(1+r) \bar{\theta}$ to determine the binding outside option. ${ }^{28}$

Extension 3: Returns in Both Periods Suppose that investment in the first period generates returns in both periods, while investment in the second period only generates

${ }^{28}$ This is true as long as the expropriation rate on investment abroad $\theta^{a}$ is in proportion to the expropriation rate on domestic investment, e.g., with $\theta^{a}=\alpha+\beta \theta \subseteq[0,1]$. That is, as long as this expropriation rate is uniquely determined by the autocrat's type $\theta$. 
returns in that period. This shifts the likelihood of investing under the current autocrat up by a constant, but does not fundamentally affect the comparative statics of the model. To see why, consider the case in which a potential autocrat cannot signal his type to economic elites. If economic elites perfectly observed the potential autocrat's type once its value was realized, their expected payoff when investing under the current autocrat would be $(1+r) \bar{\theta}+$ $r[(1-\bar{p}) \bar{\theta}+\bar{p} \theta] \cdot{ }^{29}$ Given that the potential autocrat's type is his private information, the probability of elite investment under the current autocrat becomes:

$$
\operatorname{Pr}(\text { elite investment })=\operatorname{Pr}(\theta \leq \bar{\theta} \pi)=\frac{1}{2}-\frac{\mu-\bar{\theta} \pi}{2 b},
$$

where $\pi=1+r / \bar{p}$ represents the relative loss in income to economic elites when withholding investment. While this shifts economic elites' incentives to invest under the current autocrat upward, it does not affect the comparative statistics in equation 6, as the only difference in the equilibrium probability of elite investment in equation 5 is the $\nu$ term, which becomes $\mu-\bar{\theta} \pi$ instead of $\mu-\bar{\theta}$.

Extension 4: Discounting the Future Suppose that economic elites discount the future at rate $\beta \in[0,1]$. Suppose further that the potential autocrat cannot signal his type to them. If they perfectly observed the potential autocrat's type once its value was realized, economic elites' expected payoff when withholding investment would be $\beta(1+r)[(1-\bar{p}) \bar{\theta}+\bar{p} \theta]$. However, the potential autocrat's type is his private information. As a result, the probability of elite investment under the current autocrat becomes:

$$
\operatorname{Pr}(\text { elite investment })=\operatorname{Pr}(\theta \leq \bar{\theta} \delta)=\frac{1}{2}-\frac{\mu-\bar{\theta} \delta}{2 b},
$$

where $\delta=[1-\beta(1-\bar{p})] / \beta \bar{p}$ is a discount-adjusted factor. The more impatient economic elites (i.e., the lower $\beta$ ), the higher the likelihood of elite investment. ${ }^{30}$ Equation 1 represents the special case in which $\beta=1$.

More generally, discounting the future only marginally changes economic elites' incentives to invest by making their outside option $\bar{\theta} \delta$ rather than $\bar{\theta}$. Moreover, it does not change the potential autocrat's incentives structure. As a result, the only difference in the equilibrium ${ }^{29}$ We assume that the principal is returned in the first period. ${ }^{30}$ Mathematically, $\partial \delta / \partial(-\beta)=1 / \beta^{2} \bar{p}>0$, so $\partial \operatorname{Pr}$ (elite investment) $/ \partial(-\beta)=\bar{\theta} / 2 b \beta^{2} \bar{p}>0$. 
probability of elite investment in equation 5 is in the $\nu$ term, which becomes $\mu-\bar{\theta} \delta$ instead of $\mu-\bar{\theta}$ (see appendix $\mathrm{G}$ ). This implies that elite investment is monotonically decreasing in $\beta .^{31}$ The comparative statics defined in equation 6 still hold: elite uncertainty makes elite investment under autocracy more likely.

Extension 5: The Stabilizing Impact of Investment Suppose that the likelihood of an autocrat turnover depends in part on elite investment. In particular, investment may stabilize the current dictator, for instance by providing greater rents to shore up the ruling coalition or greater resources to distribute to the population in order to mitigate unrests. Let $p=p(a ; \gamma, \bar{p})=\bar{p}-\gamma(1-a)$, with $\gamma \in[0, \bar{p}] \subseteq[0,1]$. Critically, this feature does not fundamentally affect economic elites' nor the potential autocrat's incentives structure. On the one hand, the potential autocrat has a positive payoff only when $a=1$, implying $p(1, \gamma, \bar{p})=\bar{p}$. On the other hand, economic elites still have the same outside option, $\bar{\theta} .{ }^{32}$ Consequently, the comparative statics defined in equation 6 still hold.

\section{Extension 6: Replacement by Democracy Rather than Dictatorship Suppose} that the alternative to the current autocrat is not another autocrat but rather an elected democrat. The basic difference between autocrats and democrats is that democrats only tax income flows at rate $\tau \in[0,1]$, but do not expropriate economic elites' endowment. ${ }^{33}$ Let $1-\tau$ represent the type of the potential democrat. It follows the same distribution as $\theta$. If economic elites observed the democrat's type once its value was realized, their expected

\footnotetext{
${ }^{31}$ We provide simulations for various sets of parameters in Appendix Figure G.1. Analogous mechanisms are at play whenever we allow the endowment to depreciate over time. Suppose that the endowment depreciates at rate $\gamma \in[0,1]$. If economic elites perfectly observed the potential autocrat's type once its value was realized, their expected payoff when not investing under the current autocrat would be $(1-\gamma)(1+r)[(1-\bar{p}) \bar{\theta}+\bar{p} \theta]$. As a result, when the depreciation rate increases, investment under the current autocrat is more likely.

${ }^{32}$ More precisely, economic elites would be indifferent between investing under the current autocrat and waiting until the next period when $(1+r) \bar{\theta}=p(1 ; \gamma, \bar{p})(1+r) \bar{\theta}+[1-p(1 ; \gamma \bar{p})](1+r) \theta \Longleftrightarrow \bar{\theta}=\bar{p} \bar{\theta}+(1-$ $\bar{p}) \theta \Longleftrightarrow \bar{\theta}=\theta$.

${ }^{33}$ This assumption builds from recent literature on political regimes, property rights, and expropriation
} (Albertus 2015, Ansell \& Samuels 2014). 
payoff when withholding investment would be $(1-\bar{p})(1+r) \bar{\theta}+\bar{p}[1+r(1-\tau)]$. As a result, the probability of elite investment under the current autocrat becomes: ${ }^{34}$

$$
\operatorname{Pr}(\text { elite investment })=\operatorname{Pr}\left(1-\tau \leq \frac{(1+r) \bar{\theta}-1}{r}\right)=\frac{1}{2}-\frac{\mu-[(1+r) \bar{\theta}-1] / r}{2 b} .
$$

The potential democrat's incentives are no different than those of a potential autocrat. Hence, the likelihood of elite investment is similar to equation 5 except that the $\nu$ term is replaced by $\mu-[(1+r) \bar{\theta}-1] / r$. Because democrats do not expropriate economic elites' endowment, economic elites are less likely to invest under the current autocrat when there is a future democratic rather than an autocratic opportunity. ${ }^{35}$ The comparative statics in equation 6 hold (see Appendix H).

\section{Generalizability of the Uncertainty Mechanism for Private Investment}

This section conducts two related exercises. First, it attempts to bound the likely generalizability of our uncertainty mechanism. Second, it presents an illustrative overview of a number of cases in which the mechanism has operated.

The formal model delineates two principal mechanisms that encourage private actors to invest their capital under unconstrained dictatorship: uncertainty in the pool of potential dictators and uncertainty in the informational environment. High uncertainty along these dimensions gives private actors stronger incentives to invest despite the lack of a credible commitment to property rights. Which authoritarian regime episodes have been characterized by these circumstances?

34 The derivation is as follows: $\operatorname{Pr}($ elite investment $)=\operatorname{Pr}((1+r) \bar{\theta} \geq(1-\bar{p})(1+r) \bar{\theta}+\bar{p}[1+r(1-\tau)])=$ $\operatorname{Pr}(1-\tau \leq[(1+r) \bar{\theta}-1] / r)=\{[(1+r) \bar{\theta}-1] / r-\mu+b\} / 2 b=1 / 2-\{\mu-[(1+r) \bar{\theta}-1] / r\} / 2 b$.

${ }^{35}$ Mathematically, $[(1+r) \bar{\theta}-1] / r<\bar{\theta}$ because $\bar{\theta}<1$, so that the probability of elite investment in equation 9 is strictly lower than the probability of elite investment in equation 5 . Even if the tax rate was approaching 1, economic elites might still prefer investing under the potential democrat because of the lack of risk of expropriation of their endowment as long as the current autocrat is not too aligned with their interests, i.e., as long as $\bar{\theta}<1 /(1+r)$. 
Table 1 displays a set of cases in which our mechanism is most likely to have operated. Following the discussion in Section 1, we focus on dictatorships that do not face measurable institutional constraints and that are not monarchies. Substantial private investment in these regimes is the most puzzling from the perspective of existing theory. Although we focus on investment in these regimes as likely cases of the operation of our uncertainty mechanism, it is worth underscoring that this is likely a lower bound for the scope of our mechanism: it is entirely possible for the uncertainty mechanism to operate even in institutionalized authoritarian regimes, albeit to a smaller degree to the extent that institutions reduce uncertainty over authoritarian succession and stability.

Table 1 includes all country-years of above average private domestic investment as a percentage of GDP in uninstitutionalized authoritarian regimes over the period 1970-2002. The average, $11 \%$ of GDP, is calculated for all authoritarian country-years for which data are available. ${ }^{36}$ Data on authoritarian regimes are from Cheibub, Gandhi \& Vreeland (2010).

Similar to the discussion of Figure 1 in Section 1 above, uninstitutionalized authoritarian regimes are coded as those that do not have a functioning legislature, that are not ruled by one or more dominant institutionalized political parties, and that are not monarchies. Data on legislatures, parties, and monarchies are from Geddes, Wright \& Frantz (2014) and Gandhi (2008). The temporal coverage of the table is limited by the data on authoritarian legislatures, which ends in 2002. Distinct regime episodes within a given country are separated where relevant. For instance, Argentina has two entries for authoritarian regimes; these regimes were separated by a short-lived democratic spell. Chile, by contrast, was ruled by Pinochet in all of the years listed in Table 1. Of course, Pinochet was in office even longer, from 1973-1990, but only the years indicated had above average private domestic investment.

Private domestic investment data used in Table 1 are principally taken from the World Bank. As discussed in Section 1 above, private domestic investment is calculated as gross fixed capital formation in the private sector as a percentage of GDP minus foreign direct

\footnotetext{
${ }^{36}$ In two of the cases here - the Democratic Republic of Congo (1997-2001) and Liberia (2001-2002) — natural resources rents comprise over $20 \%$ of GDP. Private investment in natural resources in these cases could also be related to political institutions.
} 
investment as a percentage of GDP. In several cases where World Bank data on gross fixed capital formation are missing, data on gross fixed capital formation from the Growth and Development Network (GDN) Growth Database are used, subtracting out foreign direct investment. ${ }^{37}$

Table 1 lists thirty cases of uninstitutionalized dictatorships with high levels of private domestic investment, typically over at least a several year period. For each case, the table lists the median value of private domestic investment for the years indicated for each regime. It also lists the number of coups in the ten years prior to the first year indicated for each case. Data on coups are from Banks \& Wilson (2015). Finally, Table 1 lists the authoritarian regime type for each case. As is evident from the table, the cases span geographic regions and time periods.

Episodes of uninstitutionalized dictatorship preceded by coups and counter-coups are good candidates for our theory since coups can generate uncertainty in the informational environment facing elites. Of course, it is possible that business interests may support a coup when they believe it will bring them a favorable dictator; investment could then be due to business-friendly policies. However, as our model highlights, business interests always face some uncertainty about whether who they support in a coup will be the "right type" once in office. Coup perpetrators have an incentive to deliberately conceal their political objectives prior to ascending to power to avoid a debate that would complicate their ability to secure the support needed to launch the coup (Stepan 1971, 216). As a result, economic elites that support a coup may fear that a dictator will transgress against their interests, and with good reason: campaigns of harassment and imprisonment of former civilian allies are common, as demonstrated by the rule of Leguia and Odría in Peru (Gilbert 1977) and by Castelo Branco in Brazil (Stepan 1971). Even more damaging to members of the coup coalition are those cases in which the actors who helped finance a coup become the chief targets of expropriation, as in the case of Peru under Velasco (Gilbert 1977, 154). Our fundamental contribution is to highlight how uncertainty over what type of a dictator will rise to power and what he will do once in office affects the behavior of investors - whether or not they support a coup to bring a new dictator to power. This is a fundamental problem for elites.

\footnotetext{
${ }^{37}$ GDN data cover the period 1970-1997.
} 
While the cases in Table 1 are authoritarian country-years where the theory most likely operates, the theory plausibly applies to a still wider range of cases. This is because data on private investment are simply missing for the majority of authoritarian countryyears - including the majority of country-years of unconstrained authoritarianism. However, the secondary literature indicates that private domestic investment in some of these cases is quite substantial, making them additional candidates for the theory's applicability. Examples include Spain under Franco during the Spanish Miracle boom years from 1959-1974 (Wright 1977) and Myanmar under military rule in the 1990s and 2000s (Fujita, Mieno \& Okamoto 2009).

Beyond the basic statistics in Table 1 that speak to generalizability, there is evidence for our uncertainty mechanism directly operating in a number of these cases. We examine two of them here for illustrative purposes.

Bangladesh. Bangladesh was ruled by a series of military and civilian dictators from the time of independence in 1971 until its first transition to democracy in 1985. The socialist Awami League rule of the early-mid 1970s gave way to factional and incoherent rule of various civilian and military rulers in the mid-1970s. A series of coups and counter-coups generated high turnover during this period. At the same time, alternative social groupings such as the Muslim Right began to gain popular followings. Both the civil bureaucracy and the military were riven with factionalism. The military's more traditional senior officer corps was increasingly challenged by both Pakistani officer repatriates as well as various factions of the younger Freedom Fighters that were at the forefront of the war of independence against Pakistan (Bertocci 1982, 995). Some of these Freedom Fighters aligned themselves with the Awami League, whereas others allied with radical leftist parties such as Jatiyo Samajtantric Dal.

General Ziaur Rahman rose to power in 1977 and ushered in temporary stability, but was assassinated by a group of dissident army officers in 1981. Another coup attempt quickly followed, as did massive wage-related strikes and growing street protests by supporters of the Awami League and the Freedom Fighters, who were implicated in the coup attempt. It was against this backdrop that army chief Hussain Ershad began to send strong signals to economic elites in late 1981 of his interests in ruling and to seek allies. As Bertocci 
(1982, 1000) writes, "in the midst of an increasingly fluid and potentially turbulent situation, General Ershad made clear, in a press interview, the army's displeasure with the growing disorder and, further, he implied strongly that the military frowned upon the prospect of a return to power of the AL [the socialist Awami League]...[T]he essential message must surely not have been lost on the voting public."

Further disintegration of political parties and military factions increased uncertainty both over an alternative leader's likely policies as well as the capacity to make credible promises to deliver specific policies given the shifting sands of political groupings. Within four months of the November 1981 elections, Ershad seized power in a coup. Against the backdrop of instability, the "March coup [by Ershad] seems to have been greeted domestically by a sigh of relief" (Bertocci 1982, 1001).

Ershad, however, was hardly a business sector lackey. He was squarely a military man, emphasizing centralization and military preeminence. Indeed, one businessman described his government as "the most centralized and corrupt in the country's history" (Kochanek 1993, 264-65). Military rulers and bureaucrats systematically extorted business for bribes in exchange for contracts, and continued demanding payments and favors as projects were rolled out. Nor was it easy for economic elites to anticipate Ershad's policies or to restrain them if they were damaging: Ershad quickly banned political parties and dissolved the parliament. Consequently, "law and policy had little meaning" and "decisions were made on an arbitrary basis with little accountability or appeal" (Kochanek 1993, 266-67).

Despite Ershad's transgressions against business and free hand over policy, he still represented a comparatively safe bet for business. He instituted a new industrial policy in 1982, which transferred a raft of industrial and commercial enterprises (such as jute and textiles) to the private sector, and cultivated ties with the business community, enabling private entrepreneurs to enrich themselves. Rather than sit on the sidelines, these entrepreneurs took the opportunity to invest with alacrity. Private investment, which had increased toward the end of Rahman's tenure, climbed still higher-and would exceed that during Bangladesh's first decade of independence and that which came after Ershad later reinstated parliament and the country transitioned to democracy.

Peru. Peru experienced a decade of narrow, autonomous and unpredictable military 
rule from 1968 to 1980 during which the legislature was shuttered and political parties were inoperative. General Velasco (1968-1975) conducted a frontal attack on traditional economic elites, nationalizing banks and the oil sector, systematically expropriating large landowners, and hobbling industrialists through profit-sharing schemes and favorable worker regulations (Albertus 2015, Ch. 6). But surprisingly, not all investors divested. After all, Velasco was an avowed anti-communist and brutally repressed the political party APRA, which had a history of supporting radical labor organizing. As late as 1973 and 1974, large landowners outside the northern coastal plantations and most sprawling highlands haciendas were shocked at being targeted with expropriation (Mayer 2009, Ch. 3).

As Velasco fell ill, his prime minister, General Morales Bermúdez, began building an army coalition to oust him. Morales publicly cultivated a reputation as a pragmatic, more conservative figure than Velasco, criticizing leftists for supporting striking workers. This garnered support from many business elites, who were willing to cast their lot with any plausible replacement who might be even somewhat more sympathetic to their interests than Velasco, especially given the possibility of more radical alternatives.

But like Velasco, Morales faced few institutional constraints, and he was hardly aligned with investors. Nonetheless, business members of the powerful export and industry confederations, with little credible guarantee of the protection of their investments but significant uncertainty over whether a Morales replacement would bring still more conservative rule or another Velasco, began investing substantially in mining, basic industry and manufacturing, urban development projects, fishing, and middle-sized farming operations. Some of these investments paid off: Morales dramatically slowed land expropriation after his first year and incorporated several key remaining industrialists into his cabinet (especially Minister of Industry Gabriel Lanata). But others got burned: land expropriation reached its apex during Morales' first year in office (Albertus 2015, Ch. 6), and in the face of an economic crisis in 1978, Morales pushed Lanata out of his cabinet (Conaghan \& Malloy 1995, 79). Many business interests subsequently turned against the regime. 


\section{Conclusion}

Existing literature offers several powerful explanations for private investment under dictatorship that help to account for why individual actors would risk the expropriation of their capital under an authoritarian regime where checks and balances on the executive are much weaker than in democracy. Perhaps most prominent are explanations that emphasize long time horizons and therefore an encompassing interest in growing the economy as a whole, and explanations that emphasize institutionalization as a way to tie the hands of the dictator and thereby reduce the likelihood of arbitrary predation on private economic actors.

Motivated by numerous cases of significant private investment under relatively unconstrained dictators that lack very long time horizons, however, this paper highlights a different and original explanation: that uncertainty over expected economic returns under plausible alternative authoritarian successors can provide incentives for private actors to invest under a current authoritarian regime even when expropriation risk is far from negligible.

We explore and unpack uncertainty over future policies theoretically, distinguishing between two interrelated mechanisms: uncertainty over the type (and therefore likely policies) of a potential autocratic successor and uncertainty in the veracity of the policy promises these successors make to economic elites. Our formal model yields predictions about how these two sources of uncertainty impact the decisions of private actors living under authoritarianism to invest in the economy in the present or withhold their capital in hopes a more favorable dictator comes to power. The comparative statics indicate that private actors who are sufficiently uncertain about what will transpire under a future episode of dictatorship may choose to invest today in order to realize returns and take advantage of a relatively more favorable investment environment.

To be sure, it may be difficult empirically to clearly distinguish between these two mechanisms of uncertainty. Those complications undergird the importance of approaching the uncertainty problem rigorously from a theoretical perspective. Furthermore, we demonstrate broadly the theory's plausibility by exploring several cases in which uncertainty on the part of private investors under dictatorship ultimately catalyzed greater investment despite considerable expropriation risk. Further empirical investigation could examine more 
systematically a broader set of cases beyond the two that we examine here to assess how the different mechanisms operate.

The two sources of uncertainty that our model highlights are not the only potential sources of policy uncertainty that investors face under dictatorship. For instance, a dictator could shift their policy over time in a way that is initially unanticipated, whether due to updating beliefs about optimal policy, a shift in the underlying coalition, or foreign pressure. Future work might fruitfully integrate this additional source of policy uncertainty into our model in an effort to explore which types of uncertainty dominate under different circumstances. 


\section{References}

Acemoglu, Daron \& James A Robinson. 2006. Economic Origins of Democracy and Dictatorship. New York: Cambridge University Press.

Albertus, Michael. 2015. Autocracy and Redistribution: The Politics of Land Reform. Cambridge University Press.

Albertus, Michael \& Victor Gay. 2017. "Unlikely Democrats: Economic Elite Uncertainty under Dictatorship and Support for Democratization." American Journal of Political Science 61(3):624-41.

Albertus, Michael \& Victor Menaldo. 2014. "Gaming Democracy: Elite Dominance During Transition and the Prospects for Redistribution." British Journal of Political Science $44(3): 575-603$.

Albertus, Michael \& Victor Menaldo. 2018. Authoritarianism and the Elite Origins of Democracy. Cambridge University Press.

Almeida, Paul. 2008. Waves of Protest: Popular Struggle in El Salvador, 1925-2005. University of Minnesota Press.

Ansell, Ben \& David Samuels. 2014. Inequality and Democratization: An Elite-Competition Approach. New York: Cambridge University Press.

Ashworth, Scott \& Ethan Bueno de Mesquita. 2006. "Monotone Comparative Statics for Models of Politics." American Journal of Political Science 50(1):214-231.

Banks, Arthur \& Kenneth Wilson. 2015. "Cross-National Time-Series Data Archive.".

Bates, Robert \& Donald Lien. 1985. "A Note on Taxation, Development, and Representative Government." Politics \& Society 14(1):53-70.

Bertocci, Peter. 1982. "Bangladesh in the Early 1980s: Praetorian Politics in an Intermediate Regime." Asian Survey 22(10):988-1008. 
Boix, Carles \& Milan Svolik. 2013. "The Foundations of Limited Authoritarian Government: Institutions, Commitment, and Power-Sharing in Dictatorships." Journal of Politics 75(2):300-316.

Castellani, Ana. 2013. "Privileged Accumulation Spaces and Restrictions on Development of State-Business Relations in Argentina (1966-1989)." American Journal of Economics and Sociology 72(1):90-121.

Celoza, Albert. 1997. Ferdinand Marcos and the Philippines. Westport, CT: Praeger.

Cheibub, José Antonio, Jennifer Gandhi \& James Raymond Vreeland. 2010. "Democracy and Dictatorship Revisited." Public Choice 143(1-2):67-101.

Conaghan, Catherine \& James Malloy. 1995. Unsettling Statecraft: Democracy and Neoliberalism in the Central Andes. Pittsburgh: University of Pittsburgh Press.

Crone, Donald. 1991. "Military Regimes and Social Justice in Indonesia and Thailand." Journal of Asian and African Studies 26(1-2):96-113.

Cunningham, Tom \& Inés Moreno de Barreda. 2015. "Equilibrium Persuasion.".

Debs, Alexandre. 2007. "Political Strength and Economic Efficiency in a Multi-Agent State.".

Evans, Peter. 1995. Embedded Autonomy: States and Industrial Transformation. Princeton: Princeton University Press.

Fujita, Koichi, Fumiharu Mieno \& Ikuko Okamoto. 2009. The Economic Transition in Myanmar After 1988. Singapore: National University of Singapore Press.

Gandhi, Jennifer. 2008. Political Institutions Under Dictatorship. New York: Cambridge University Press.

Geddes, Barbara, Joseph Wright \& Erica Frantz. 2014. "Autocratic Breakdown and Regime Transitions: A New Data Set." Perspectives on Politics 12(2):313-331. 
Gehlbach, Scott \& Philip Keefer. 2011. "Investment Without Democracy: Ruling-Party Institutionalization and Credible Commitment in Autocracies." Journal of Comparative Economics 39(2):123-139.

Gehlbach, Scott \& Philip Keefer. 2012. "Private Investment and the Institutionalization of Collective Action in Autocracies: Ruling Parties and Legislatures." Journal of Politics 74(2):621-635.

Gilbert, Dennis. 2017. The Oligarchy and the Old Regime in Latin America, 1880-1970. Lanham: Rowman and Littlefield.

Goemans, Henk, Kristian Skrede Gleditsch \& Giacomo Chiozza. 2009. "Introducing Archigos: A Dataset of Political Leaders." Journal of Peace Research 46(2):269-283.

Haber, Stephen, Noel Maurer \& Armando Razo. 2003. The Politics of Property Rights. New York: Cambridge University Press.

Herb, Michael. 1999. All in the Family: Absolutism, Revolution and Democracy in the Middle Eastern Monarchies. New York: SUNY Press.

Huber, Evelyne, Thomas Mustillo \& John Stephens. 2008. "Politics and Social Spending in Latin America." Journal of Politics 70(2):420-36.

Jensen, Nathan, Edmund Malesky \& Stephen Weymouth. 2014. "Unbundling the Relationship Between Authoritarian Legislatures and Political Risk." British Journal of Political Science 44(3):655-84.

Kochanek, Stanley. 1993. Patron-Client Politics and Business in Bangladesh. New Delhi: Sage Publications.

Krueger, Anne. 1974. "The Political Economy of the Rent-seeking Society." American Economic Review 64(3):291-303.

Levi, Margaret. 1989. Of Rule and Revenue. Berkeley, CA: University of California Press.

Magaloni, Beatriz. 2008. "Credible Power-Sharing and the Longevity of Authoritarian Rule." Comparative Political Studies 41(4-5):715-741. 
Mares, Isabela \& Didac Queralt. 2015. "The Non-Democratic Origins of Income Taxation." Comparative Political Studies 48(14):1974-2009.

Mayer, Enrique. 2009. Ugly Stories of the Peruvian Agrarian Reform. Durham: Duke University Press.

Myerson, Roger. 2008. "The Autocrat's Credibility Problem and Foundations of the Constitutional State." American Political Science Review 102(1):125-139.

North, Douglass. 1990. Institutions, Institutional Change and Economic Performance. Cambridge: Cambridge University Press.

North, Douglass \& Barry Weingast. 1989. "Constitutions and Commitment: The Evolution of Institutions Governing Public Choice in Seventeenth-Century England." Journal of Economic History 49(4):803-832.

North, Douglass \& Robert Paul Thomas. 1973. The Rise of the Western World: A New Economic History. Cambridge University Press.

Olson, Mancur. 1993. "Dictatorship, Democracy, and Development." American Political Science Review 87(3):567-576.

Pond, Amy. 2018. "Financial Liberalization: Stable Autocracies and Constrained Democracies." Comparative Political Studies 51(1):105-135.

Przeworski, Adam, Michael Alvarez, Jose Antonio Cheibub \& Fernando Limongi. 2000. Democracy and Development. New York: Cambridge University Press.

Schneider, Ben Ross. 2004. Business Politics and the State in Twentieth-Century Latin America. New York: Cambridge University Press.

Slater, Dan. 2010. Ordering Power. New York: Cambridge University Press.

Sonin, Konstantin. 2003. "Why the Rich May Favor Poor Protection of Property Rights." Journal of Comparative Economics 31(4):715-731. 
Svolik, Milan. 2012. The Politics of Authoritarian Rule. New York: Cambridge University Press.

Wilson, Matthew \& Joseph Wright. 2017. "Autocratic Legislatures and Expropriation Risk." British Journal of Political Science 47(1):1-17.

Wintrobe, Ronald. 1998. The Political Economy of Dictatorship. New York: Cambridge University Press.

Wright, Alison. 1977. The Spanish Economy, 1959-1976. London: MacMillan Press. 
Table 1: Uninstitutionalized Authoritarian Regimes with High Private Domestic Investment

\begin{tabular}{|c|c|c|c|c|}
\hline Country & Years & $\begin{array}{c}\text { Private Domestic } \\
\text { Investment (\%GDP) }\end{array}$ & $\begin{array}{c}\text { Coups in } \\
\text { Prior Decade }\end{array}$ & Regime Type \\
\hline Algeria & $1970-76$ & 24.44 & 1 & Military \\
\hline Algeria & 1992 & 19.76 & 0 & Military \\
\hline Argentina & 1970-72 & 15.63 & 2 & Military \\
\hline Argentina & $1976-82$ & 16.96 & 3 & Military \\
\hline Bangladesh & $1982-85$ & 11.85 & 3 & Personal \\
\hline Chile & $1978-81 ; 1985-88$ & 13.56 & 1 & Military/Personal \\
\hline Congo & 1978 & 17.15 & 1 & Military \\
\hline Congo & 1991 & 17.56 & 0 & Military \\
\hline Congo & $1997-98 ; 2000-01$ & 17.91 & 0 & Personal \\
\hline Ecuador & 1976-78 & 16.02 & 2 & Military \\
\hline El Salvador & 1979 & 12.28 & 0 & Military \\
\hline Guinea & 1994 & 11.25 & 1 & Personal \\
\hline Honduras & $1974-80$ & 13.54 & 1 & Military \\
\hline Korea, South & 1980 & 23.80 & 0 & Military \\
\hline Lesotho & $1987-92$ & 32.18 & 1 & Military \\
\hline Liberia & 2001-02 & 17.90 & 0 & Personal \\
\hline Mali & $1971-73 ; 1975 ; 1977-78$ & 13.80 & 1 & Personal \\
\hline Mauritania & 1985-1991 & 17.47 & 3 & Personal \\
\hline Niger & $1977-1981$ & 16.12 & 1 & Military/Personal \\
\hline Nigeria & $1971-78$ & 17.40 & 2 & Military \\
\hline Peru & 1970-71;1973-79 & 14.68 & 2 & Military \\
\hline Peru & 1992-93 & 12.44 & 0 & Personal \\
\hline Philippines & $1972-77$ & 15.79 & 0 & Personal \\
\hline Sudan & 1973 & 12.18 & 2 & Personal \\
\hline Sudan & 1992-93 & 14.25 & 3 & Personal \\
\hline Thailand & 1976-78 & 17.36 & 2 & Military \\
\hline Thailand & 1991 & 32.36 & 0 & Military \\
\hline Togo & $1974-75 ; 1977-78$ & 15.85 & 1 & Personal \\
\hline Uganda & 1971 & 12.00 & 0 & Personal \\
\hline Uruguay & $1974-79 ; 1981-82$ & 11.92 & 0 & Military \\
\hline
\end{tabular}

Note: This table displays all country-years of above average private domestic investment as a percentage of GDP in uninstitutionalized authoritarian regimes over the period 1970-2002. In several exceptional cases included in the table, military regimes have a single party hybrid component (Algeria, Congo, El Salvador); the military in these cases was nonetheless dominant. 


\section{Figure 1: Private Domestic Investment Under Different Political Regimes}

(a) Private Domestic Investment Under

Dictatorship and Democracy

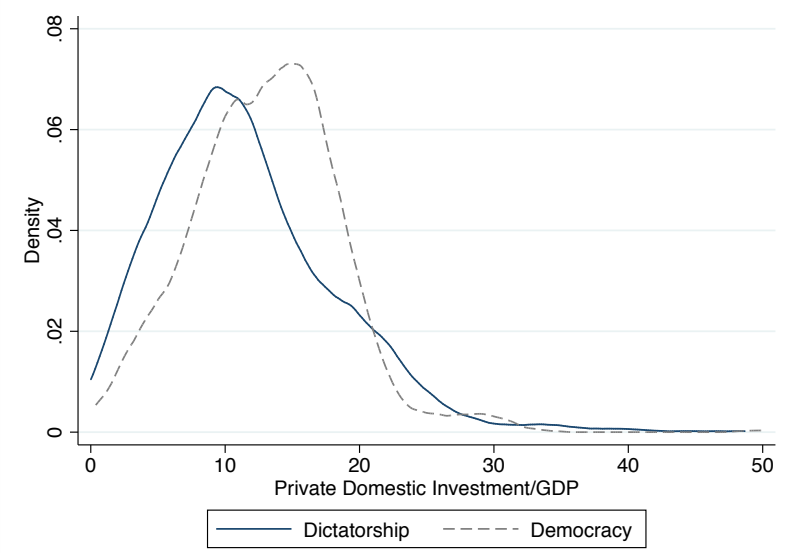

(b) Private Domestic Investment by Regime Institutionalization Under Dictatorship

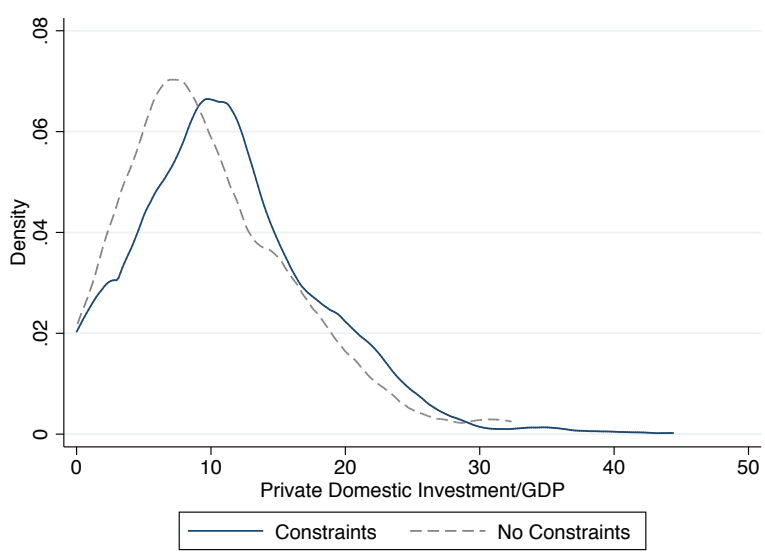

Note: Dictatorships coded as having constraints in Figure 1b are those that have a functioning legislature or one or more dominant, institutionalized political parties, as well as monarchies.

Figure 2: Densities of Types of Potential Autocrats

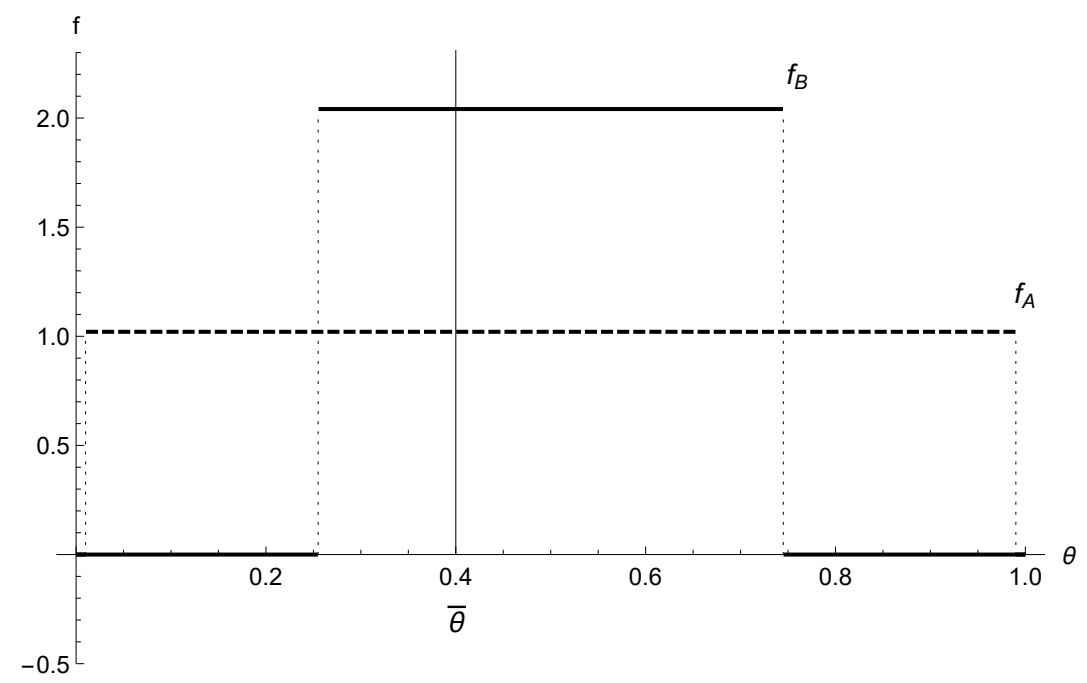

Parameters: $\mu=0.5, \bar{\theta}=0.4, \sigma_{A, \theta}^{2}=0.08$ (dashed line) and $\sigma_{B, \theta}^{2}=0.02$ (solid line) 
Figure 3: Elite Investment under Two Regime Variances

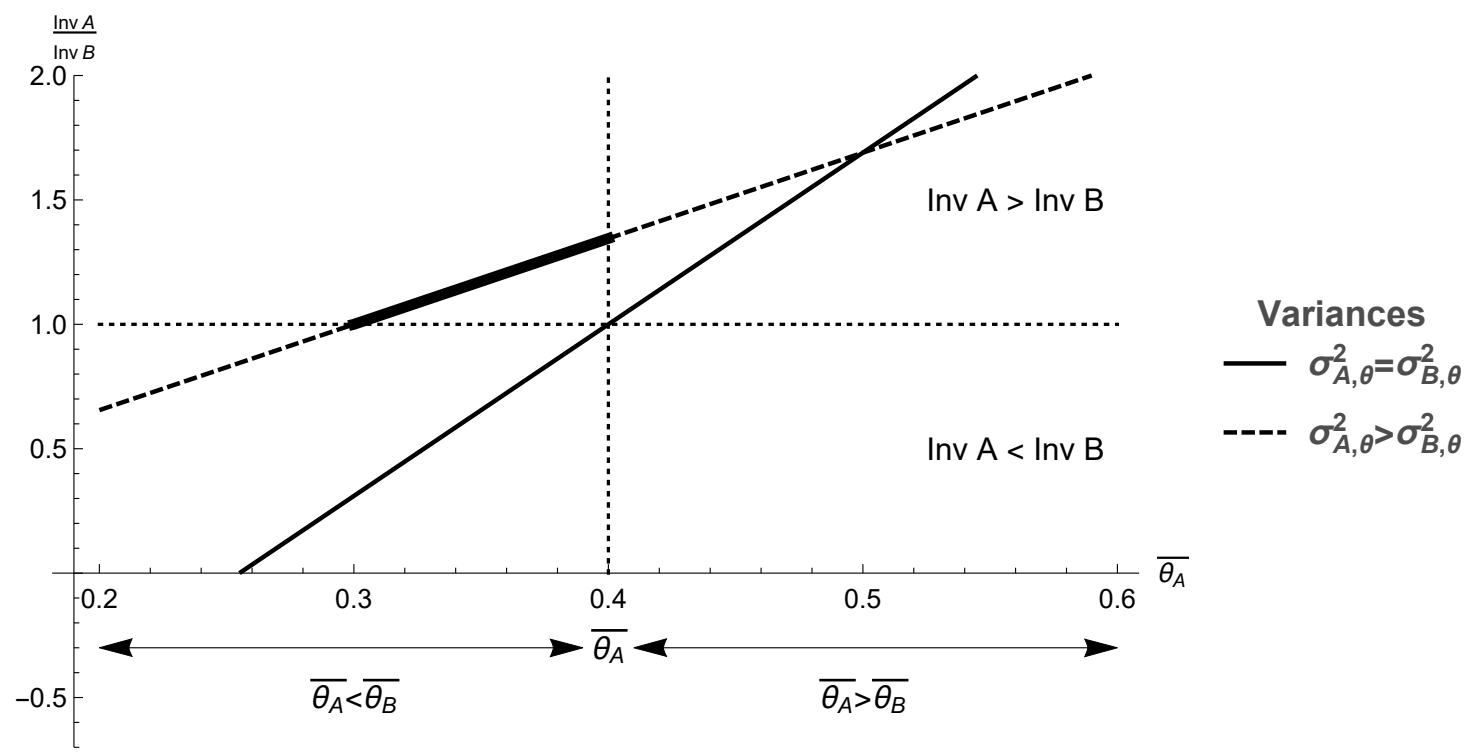

Parameters: $\mu=0.5, \sigma_{A, \theta}^{2}=0.08$ (dashed line), and $\sigma_{B, \theta}^{2}=0.02$ (solid line). Inv $A$ corresponds to investment under Regime A. Inv $B$ corresponds to investment under Regime B.

Figure 4: Elite Investment under Two Regime Variances and Two Informational

\section{Environments}

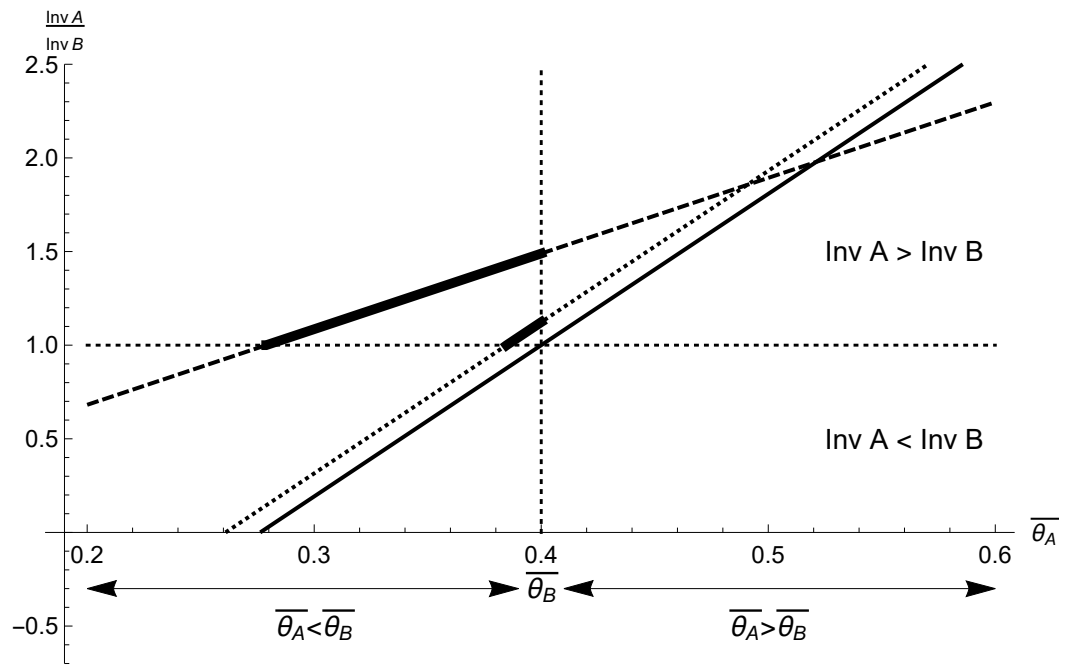

Parameters: $\mu=0.5, c=50, \bar{p}=0.75, \sigma_{A, \theta}^{2}=0.08$ (dashed line), $\sigma_{B, \theta}^{2}=0.02, \sigma_{B, u}^{2}=0.01$, and $\sigma_{A, u}^{2}=0.20$ (dotted line). Inv $A$ corresponds to investment under Regime A. Inv $B$ corresponds to investment under Regime B. 